\title{
Family or Old Age Home - Which is Appropriate for Happiness of Elderly at Post Retirement Life in India? : A Reflection from a Study
}

Harasankar Adhikari*

Monihar Co.H. Society, Kolkata, India

"Corresponding author: Harasankar Adhikari, West Bengal, Kolkata, India, Tel: +91-974831763; E-mail: jaoya123@yahoo.co.in

Rec date: Apr 25, 2016; Acc date: May 19, 2016; Pub date: May 21, 2016

Copyright: $\odot 2016$ Adhikari $\mathrm{H}$. This is an open-access article distributed under the terms of the Creative Commons Attribution License, which permits unrestricted use, distribution, and reproduction in any medium, provided the original author and source are credited.

\section{Short Communication}

The family is culturally the best place for the elderly at their post retirement life in India. They prefer their living arrangement with children and grandchildren which is significant for happiness. But globalization and urbanization have brought changes in this cultural system with an effect of socio-economy and political condition. The elderly population ceases to be functional, they are considered as a 'burden' upon the family and ending up in old age home [1]. Joint family system turns into a nuclear family (a family group consisting of a pair of adults and their children), and the family contents only parents, son/daughter and grandchild (ren). There is limited living space of the elderly in this type of family in urban or rural India. Consequently, they shift to old age home where they only count their end days of life [2]. In their old age home, they suffer from various psychosocial and environmental problems including feeling of neglect, loss of importance in the family, loneliness and feeling of unwantedness in family as well as society, feeling of inadequacy and obsolescence of skills, education, and expertise [3].

This study tried to narrate the story of elderly population who were at family and old age home with an object to find out family or old age home, which was more suitable for their happiness at post retirement life. For this purpose of this study, random sample chose to select 200 elderly informants from both rural and urban area. Of them, 100 elderly informants were living with their off-spring at their family and another 100 elderly were at inmates of old age home. Both qualitative and quantitative data were collected on their living status and role of their living space and care manager for their satisfaction and happiness.

The study investigated that after almost 10 years living in the old age home, the elderly inmates were mentally ill and they felt alone. Old age home was a life supporting place for them in a situation where they had no other option of living space with requisite facilities i.e. food, medical support and so forth [4]. In old age home, $82 \%$ elderly were missing their grandchildren very much and they reminiscenced their association with their family members. They depressed due to irregular or infrequent visit of their family members. They lived in truncated network of relationship in old age home. They were less interested to be associated with their fellow inmates due to differences in their attitude and behaviour.

But the elderly people who were at their own family, they were mentally in better position. About $52 \%$ of them were not getting requisite support and help from their immediate family members. But they shared that they were very much happy to live under one roof. The family network of relationship supported psychological well-being of elderly whose living space was their family.

Therefore, in India culture old age home does not promote a happy living and happy ending of post retirement life. Old age home makes elderly root less and it could not be ultimate alternative for happy ending of this most respectful section of the society. There is need of more studies on the subject to integrate the elderly at their family or they would be placed at old age home.

\section{References}

1. Sahoo AK, Andrews GJ, Rajan SI (2009) Sociology of Aging. Rawat Publication, New Delhi, India.

2. Lynn MD, Sharma KL (2011) Ageism and Elder Abuse. Rawat publications, New Delhi, India

3. Aacharya A (2012) Depression, loneliness and insecurity filling among the elderly female, living in old age homes of Agartala. Indian Journal of Gerontology 26: 524-536.

4. Praad BD, Rani NI (2007) Older Persons, and Caregiver Burden and Satisfaction in Rural Family Context. Indian Journal of Gerontology 21: 216-232. 